\title{
Unique Brand Extension Challenges For Luxury Brands
}

Nicole Stegemann, (E-mail: n.stegemann@uws.edu.au), University of Western Sydney, Australia

\begin{abstract}
This article addresses the impact of brand extensions on the brand equity of luxury brands. A review of the developments in the luxury market has shown significant changes in demand and supply sides. The luxury market has been growing rapidly over the last 20 years, and luxury brands, formerly reserved for a small group of privileged individuals, are now available to more consumers. Meanwhile, luxury goods manufacturers have been applying new marketing strategies, and extending their brands without any insights as to the consequences for their brands. Despite these changes, little research has investigated the luxury market. Therefore, a systematic review has been undertaken regarding the nature of luxury brands and research measuring individual luxury brand equity elements such as attitudes and perceptions. Deviating results in the application of concepts for non-luxury brands to luxury brands have been found due to the abstract and emotional nature of luxury brands. These results support the development of distinct brand equity constructs for luxury brands. The main focus of this article is the impact of luxury brand extensions on the parent brand's equity and the proposal of a framework to allow the impact to be measured.
\end{abstract}

\section{INTRODUCTION}

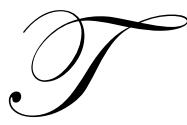

his article will explore the impact of brand extensions on the brand equity of luxury brands. The first section is a concise presentation of existing brand equity constructs followed by a brief description of brand extensions. The second part addresses the history and development of the luxury market. The next section is devoted to the systematic review of research that has addressed individual brand equity elements for luxury brands such as attitudes towards and perceptions of luxury brands. A conceptual model exploring the impact of brand extensions is proposed addressing the impact of luxury brand extensions on the parent brand's brand awareness, brand image, consumer perceived attitudes, and consumer perceived benefits of luxury brands. This article finishes off with a short section on conclusions and future research.

\section{CURRENT BRAND EQUITY CONSTRUCTS}

In the past, companies gained a competitive advantage by achieving economies of scale through improved technology applications and imperfect market conditions with respect to resource allocation such as labour and capital. However, what used to be a market of small players has turned into a playground for multinational companies competing for the world market. Most industries have been challenged by developments such as an increase in competition and product saturation (2002), increase and fragmentation of media options, busier and more price sensitive and sophisticated consumers. Thus, a common strategy is to acquire well-known consumer brands (Freeman and Sloan 1989), which companies pay large amounts for. A brand's image has become a salient resource and possible source to gain a competitive advantage. Another common motive is to leverage the value of brands through brand extensions and increase overall value of brand and investment (Tauber 1988). Product extensions also assist in managing the increased competition in distribution channels and rising advertising cost (Aaker 1991). 
Reviewing the literature on brand equity, various brand equity constructs exist. The Marketing Science Institute (Leuthesser 1988) summarised brand equity as

The set of associations and behaviours on the part of the brand's consumers, channel members, and parent corporation that permits the brand to earn greater volume or greater margins than it would without the brand name and that gives the brand a strong, sustainable, and differentiated advantage over competitors.

The underlying determinants of consumer-based brand equity are that brands provide benefits to consumers by differentiating products, as they facilitate the processing and retrieval of information (Hoyer and Brown 1990). Swait, Erdem, Louviere and Dubelaar (1993) described brands as a signal or cue regarding the nature of product and service quality and reliability and image/status, hence, they have both information functions (indirect purchase use) and image functions (direct benefit/cost). Kamakura and Russel (1993) evaluated a brand's consumer based brand equity to each product category from different stages of the consumer decision process. They defined brand equity as an intangible value (e.g. brand name association, perceptual distortions) attributed to a product by virtue of its brand name, which cannot be directly attributed to the physical product. Brand equity is the utility intrinsic to a brand that cannot be captured through its tangible characteristics (physical product attributes) and its short-term price.

Keller (1993) described consumer-based brand equity using brand descriptions based on brand awareness, images and strong, favourable, and unique consumer associations. Blackston ((1995) added a personality element to this concept, and distinguishes two components of brand equity i.e. brand value and brand meaning (attitudes, images, association, and personality). Aaker (1996) offered a very comprehensive definition of brand equity as: (1) Loyalty (brand's real or potential price premium), (2) loyalty (customer satisfaction based), (3) perceived comparative quality, (4) perceived brand leadership, (5) perceived brand value (brand's functional benefits), (6) brand personality, (7) consumers' perception of organisation (trusted, admired or credible), (8) perceived differentiation to competing brands, (9) brand awareness (recognition \& recall), (10) market position (market share), prices and distribution coverage. Ambler (1997) examined whether brand equity is explained by trust. Dyson (1996) and Heath (1997) suggested to add a commitment/bonding component to brand equity and analyse audience relationship with the brand - territory brand occupies in the audience's mind.

A BBDO study (1988) revealed that consumers are more likely to differentiate brands within categories rather on emotional appeals such as alcoholic beverages rather than on rational appeals such as those used in cleaning products. Biel (1992) explained this outcome by the marginal functional differences between brands, and that emotional image characteristics such as brand personality relate less to physical attributes. Biel (1992) also added that the metaphorical and symbolic vocabularies offer more variety, and once established these associations are more enduring. Further, brand personalities are more engaging and encourage an increased consumer processing and interpretation of a brand's image that it becomes more personally meaningful. This is especially true for luxury brands for which brand image can be seen as the salient component, when consumers purchase luxury brands, as they are mostly influenced by non-personal motives, which means they are concerned with other people's responses.

\section{BRAND EXTENSIONS}

In order to increase a brand's equity, a common strategy is to extend brands. Brand extensions allow companies to reduce risks and costs of launching new products (Tauber 1981, 1985); increase sales/profit (RoedderJohn, Loken and Joiner 1998) and market share (Smith and Park 1992); and be able to ask a premium price (Swait et al. 1993). They may also enhance and facilitate a brand's awareness; increase the consumer perceived value of brand (Aaker 1990; Keller 2003), widen a brand's attributes and add value to a brand (Levy 1997; Milberg, Park and McCarthy 1997). For successful brand extensions, consumers have to be able to expand the scope of the brands image and information cues to other areas; suppliers have to be able to increase the number of consumers that will accept the image and/or information function of the extension (Keller 1993).

Most brand extensions occur as line extensions, which use the existing brand names and products and extend them into new sizes, flavours, ingredients, etc. in the existing product category. These extensions are seen as very low risk to both company and consumers due to low introduction cost and the target market's product familiarity. 
Consumers often welcome the increased variety, as it provides them with more choice and satisfies their variety seeking needs (Kahn 1998). Category extensions involve a higher risk, as both existing and new consumers are motivated to buy very different products, which have been created from existing brand names and extended to newproduct categories. The introduction costs are higher compared to line extensions due to intermediaries' and consumers' unfamiliarity with the product, which results in increased marketing communications expenditures and distribution channel cost.

Most brand equity and brand extension research has exclusively focused on the market for non-luxury brands. This article will focus on brand equity constructs and the impact of brand extensions for luxury brands.

\section{LUXURY BRANDS}

Many luxury brands have a long history with their origin in France, and many luxury goods manufacturers such as Louis Vuitton, which celebrated its 150 year anniversary in 2004 (LVMH 2005), have been around for a long time. For years the luxury goods industry enjoyed its exclusive position in the market and a fairly stable market environment. However, supply and demand patterns for the market for luxury brands have changed considerably due to increased global competition (Roux and Floch 1996) and counterfeited luxury goods (Arghavan and Zaichkowsky 2000).

The luxury industry, established by the French "Haute Couture" with its focus on art and aesthetics, went through dramatic changes due to changed market conditions. The formerly French family run businesses either disappeared or merged into large multinational companies (Roux and Floch 1996). Further, distinct marketing strategies applied by luxury goods manufacturers (Dubois and Laurent 1994) had to be carefully monitored due to changes in supply and demand for luxury goods and brands. Researchers pointed out that little research had been done to support the applied strategies for luxury brands (Andrus, Silver and Johnston 1986).

The concept of luxury is complex, as it is subjective and primarily built on consumer perceptions, as the meaning of luxury is determined by personal and interpersonal motives (Vigneron \& Johnson 2004). To fully understand the complexity of luxury a description of the nature of luxury, luxury goods, and luxury brands takes place before discussing the concept of brand equity for luxury brands.

The origin of the word luxury is derived from the Latin words "luxus" and "luxuria" (Roux and Floch 1996). According to dictionaries, luxury compares with extravagance, opulence (UBC Sunsite n.d.), and rankness (University of Notre Dame n.d.) ${ }^{1}$ The word luxury should have a positive value of splendour to it. However, it takes on the negative meaning of decadence when used in association with 'private' and 'excess', and put into a social context (Roux and Floch 1996). Luxury is to be seen as a "manière de vivre" (a way of life). It is about pleasure, refinement, perfection and rarity, as well as appreciation, but not necessarily price (Roux and Floch 1996). Luxury is commonly defined through very limited supply and recognition of value by other people. Dubois, Laurent and Czellar (2001) proposed a definition of the nature and characteristics of the concept of luxury, and identified six facets: 1) excellent quality, 2) very high price, 3) scarcity and uniqueness, 4) aesthetics and polysensuality, 5) ancestral heritage and personal history, and 6) superfluousness.

Kapferer (1997, p.253; as cited in Vigneron and Johnson 2004) summarised luxury as follows:

Luxury defines beauty; it is art applied to functional items. Like light, luxury is enlightening. [...] They offer more than mere objects: they provide reference of good taste. That is why luxury management should not only depend on customer expectations: luxury brands are animated by their internal programme, their global vision, the specific taste which they promote as well as the pursuit of their own standards ... Luxury items provide extra pleasure and flatter all senses at once ... Luxury is the appendage of the ruling classes

1 luxuria: luxury, extravagance, opulence. (www.sunsite.ubc.ca/LatinDictionary); luxuria -ae f. [rankness, exuberant growth; excess, dissipation, extravagance]; luxus -us m. [luxury, excess, extravagance]. (www.nd.edu/ archives/latgramm.htm). 
Bourne (1957) defined luxury goods as exclusive products not commonly owned or used, which are more conspicuous than necessity products. Luxury goods are primarily branded goods purchased for psychological needs such as increase of esteem; functional needs seem to only play a secondary role in purchase decisions (Arghavan and Zaichkowsky 2000).

Luxury brands can be described as premium priced brands that consumers purchase for their psychological values (symbolic and hedonic), and not predominately for their economical and functional value (Nueno and Quelch 1998). Thus, luxury brands' nature can be characterised as conspicuous, unique, social, emotional, and of high quality (Vigneron and Johnson 1999). Due to different interactions on a personal and social level, consumers will develop different perceptions of luxury brands. In other words, the definition of luxury brands varies according to combinations of motivations based on values. The main motivations for purchasing luxury brands are the need for sociability and self-expression (Vigneron and Johnson 1999).

There has been a noticeable increase in interest in the concept of luxury, which has been acknowledged by two leading French marketing research journals ${ }^{2}$ that have published special issues on researching luxury brands. Previous research has focused largely on sociodemographic characteristics (Leibenstein 1950; Bourdieu 1979; Mason 1981; Andrus et al. 1986; Hirschman 1988; LaBarbera 1988; Stanley 1989; Dubois 1992; Dubois and Duquesne 1993; Dubois and Laurent 1993; Kapferer 1997; Wong and Ahuvia 1998). Few research studies investigated consumers' attitudes towards the concept of luxury (Dubois and Laurent 1994; Wong and Ahuvia 1998; Wong and Zaichkowsky 1999), people's relative position on luxury brands (Weber and Dubois 1995), consumers' buying motives (Kapferer 1998; Vigneron and Johnson 1999), the concept of luxury (Kapferer 1997), and perceptions of luxury brands (Vigneron and Johnson 2004).

By tradition, individuals consume luxury goods because of their desire to differentiate themselves (Baudrillard 1968; Baudrillard 1970) by either being part of their reference group, or to separate themselves from other groups preferably to be become part of a higher social class. The upper social class consumed luxury goods to distance themselves from the working class that consumed necessity goods (Bourdieu 1979). These individuals never consume goods for their economical value but their social status value. This 'Affluent' segment (Stanley 1989) was differentiated into 'Old money' (Aldrich 1988; Hirschman 1988) and 'Nouveaux Riches' (LaBarbera 1988). The 'Affluent' basically buy luxury goods all the time to satisfy their needs for material immortality (Hirschman 1990), it is a lifestyle choice for them. The "Excluded", represented the majority of the population, and did not have access to luxury (Dubois and Laurent 1995).

In the 80 's, luxury goods that used to belong to the upper class became visible, recognisable, and accessible to the public. Hence, the market for luxury goods went through an enormous demand growth spurt, and developed into a significant economic sector in the 90's (Roux and Floch 1996). For example, Louis Vuitton reported sales of nearly 2.5 billion Euros, increasing its net income by $80 \%$ between 2002 and 2004 (LVMH 2005).

The traditionally affluent clientele extended to a large middle class consumer base (Roux and Floch 1996); also described as "excursionists" (Dubois \& Laurent 1995, 1996). These new consumers oppose the traditional ostentatious consumption of luxury brands, and display a real need for emotional satisfaction (Roux and Floch 1996). They are more occasional and selective, and carefully evaluate the value of a brand (Roux and Floch 1996). Due to these changes in the market place for luxury goods, the dichotomous approach segmenting the luxury market into two segments defined by their economic resources: the 'Affluent' and the 'Excluded' or conspicuous consumption (Mason 1981) are not sufficient anymore. Nowadays, the majority of consumers buying luxury brands are the 'Excursionists' (Dubois and Laurent 1996) also called the 'Democrats' (Dubois et al. 2001), who buy luxury products and brands occasionally. The other two segments identified by Dubois et al. (2001) are the 'Elitists' representing the traditional affluent segment, and the small 'Distance' segment not interested in luxury at all. This development in the luxury market further supports a review of existing marketing approaches, where the newly identified consumer segments have to be used to design marketing strategies for luxury brands.

2 Revue Française du Marketing, 132-133 (1991), and Décision Marketing, 9 (1996). Further, the business school ESSEC - Paris offers a MBA program that specialises in luxury marketing to foster further research. 


\section{BRAND EQUITY ELEMENTS OF LUXURY BRANDS}

Though there has been some research examining individual brand equity elements such as attitudes and perception, little research has dealt with comprehensive brand equity constructs. Researchers have pointed out the abstract nature of the concept of luxury, and the impact on marketing strategies for luxury goods and brands. For example, Roux (1995) found that perceived quality is taken for granted with luxury brands, as evaluations take place on an abstract level, e.g. image related level instead on a concrete/product related level as for non-luxury brands.

Dubois \& Paternault (1995) established a relationship between the dream value (desire to own the brand), and brand awareness as well as purchasing behaviour. Their studies conducted in North America showed that brand awareness has a positive impact on the dream value, but if consumers buy the brand the dream value for that specific brand decreases. Wong \& Zaichowsky (1999) replicated the study in Hong Kong, and found that the greater the brand image, and the brand awareness amongst users, together with the perceived quality of luxury brands, the greater the brand preference and purchase rate. This relationship led to increased loyalty and sales. The authors also found that consumers hardly ever buy luxury brands they are not familiar with. Furthermore, Hong Kong consumers' dream value did not decrease after having purchased a specific brand, which appeared to be the outcome in North America (Dubois and Paternault 1995).

Dubois \& Laurent (1994) and Dubois et al. (2001) showed that consumers' attitudes towards the concept of luxury differ considerably to those of non-luxury brands. They found that attitudes towards the concept luxury are ambivalent, as consumers hold strong positive and/or negative connotations towards luxury. Only few individuals feel indifferently about luxury. Individuals spontaneously associated the term luxury with expressions such as upscale, quality, good taste, and class, but also included flashiness and bad taste. Though the terms were close to each other, they did have definite meanings. For instance, upscale products are usually related to material goods, while luxury describes symbolic and cultural values. The dual nature in luxury can be explained by avoidance and attraction reactions depending on whether individuals refer to 'their own' luxury or 'others'. They are ambivalent across and within consumers, as consumer behaviour is inconsistent with self-reported attitudes, as consumers can't understand their own contradictions (Otnes, Lowrey and Shrum 1997). Though, most people had positive attitudes towards the concept of luxury while confirming their relative lack of expertise and few luxury purchases. The majority pointed out hedonic motives and reject snobbish reasons for luxury. The negative comments included that people buy luxury goods to copy the affluent, and want to be different (Dubois et al. 2001). Affluent consumers commonly possess positive attitudes towards the concept of luxury (Dubois et al. 2001), as luxury seems to be part of their life. Occasional consumers are more critical, as they are less familiar with luxury products. They can also be unsure about the purchase, which is expressed in their often ambivalent attitudes towards the concept of luxury (Dubois et al. 2001).

Vigneron \& Johnson (1999) further investigated the concept of luxury and reviewed the latent structure of it, and the interrelations among factors. Their findings indicated that the consumer decisions making process includes five main factors when assessing luxury brands. These five dimensions are categorised as non-personal-oriented perceptions (conspicuousness, uniqueness, and quality), and personal-oriented-perceptions (hedonism and extended self). In 2004, Vigneron \& Johnson introduced a clearer definition of luxury and developed a conceptual framework and a scale for the measurement of the degree of perceived luxury of a brand. The objective is to contrast luxury and prestige, whereas luxury is used when relating to brand categories. The term 'luxury' is applied in a wider context, and includes personal and non-personal motives. The term 'prestige' is applied when referring to the extreme end of the luxury-brand category. Prestige brands relate to interpersonal motives, as consumers make purchases to decorate one's ego. The authors emphasise that the level of luxury varies from 'very little' to 'a great deal' of luxury, which means luxury brands differ with respect to their degree of luxury. In other words, consumers perceive a certain degree of luxury in brands, which determines the psychological value they see in a brand.

Vigneron \& Johnson (2004) concurred with previous research and further pointed out that the consumer decision making process for luxury brands is different and traditional marketing strategies do not apply to them. As mentioned earlier, other researchers emphasised that the changed demand and supply structures in the steadily growing luxury market require new segmentation strategies (Dubois and Laurent 1995; Dubois and Laurent 1996; Roux and Floch 1996), which further support the necessity for increased research into the luxury market. 


\section{BRAND EXTENSION STRATEGIES OF LUXURY BRANDS}

Many leading luxury goods companies have been applying extension strategies such as new product lines, product categories, and brand names. For example, French companies originally known for luxury products due to their long history of "Haute Couture" have extended their brands widely. Examples are Christian Dior (prêt-a-porter fashion, perfumes, cosmetics, skin care products, and jewellery), Hermes (prêt-a-porter fashion, watches, and china) (Roux and Boush 1996). The image of a luxury brand is mainly based on favourable strong associations based on mostly symbolic product characteristics. Thus, consumer attitudes towards luxury brands are determined by personally expressive attributes (Park, Jaworski and Macinnis 1986; Park, Milberg and Lawson 1991).

Roux (1995) examined whether previous results on brand extensions (Aaker and Keller 1990) are transferable to the symbolic market of luxury goods. Consumer evaluations on brand extensions were measured by two dependent variables, perceived quality and extension buying intention, which were both measured by the reflective measures conceptual fit, perceived quality of original brand, and transferability (usefulness of original brand know-how necessary to make the extension). In contrast to Aaker and Keller (1990) results, this study found a positive direct relationship between the evaluation of quality of the luxury parent brand and of its extension. The results for perceived extension quality showed that the measures conceptual fit and perceived brand quality represent the main predictors; transferability contributed significantly but to a lower extent. This outcome is explained by the nature of luxury brands, as consumers evaluate extensions on the abstract image-related level. Non-luxury goods and brands are mainly evaluated on a concrete/product level. Thus, luxury parent brand quality is a suitable predictor of extension perceived quality. The results for buying intention of luxury brand extensions revealed conceptual fit as the only main predictor. Though, a low but significant interaction effect between brand quality and conceptual fit was discovered. Perceived quality was seen as inherent for luxury brands by consumers due to their high involvement in the purchasing process, and their symbolic purchasing motives. Both dependant variables showed a low correlation, which confirms these two variables as independent dimensions. These results concurred with the findings that 'Excursionists' make up for a large part of the market (Dubois and Laurent 1996). The conflict with previous results (Aaker and Keller 1990) can be explained by the nature of luxury brands. Consumers expect luxury brands to be of high quality, and hence, perceived quality and purchase intention are not correlated. Purchase intention for luxury brands is rather influenced by factors such as symbolic features, product involvement, and competition (Roux 1995). Further, luxury brands that have been largely extended show a greater level of perceived quality of brand extensions than those less extended (Roux 1995). It appears that luxury brands that extended into different categories strengthened their core image, which in turn allows them to even further extend their brand (Roux 1995). This research did not address whether the brands were still limited within each category.

Roux and Boush (1996) built upon the research by Roux (1995) and examined the effect of consumers' brand knowledge on both their evaluations of luxury brand extensions and their inferences about their effect of the extensions on the original brand. They found that brand knowledge positively effects quality perceptions of potential brand extensions. However, they did not find support that greater brand knowledge has an effect on conclusions about the effect of brand extensions on the parent brand. Consumers showed a favourable attitude towards luxury brand extensions, which were predominately evaluated with respect to their conceptual fit with the parent brand (Roux and Boush 1996). They found that purchasers of luxury brands hold a high level of product knowledge, experience, and brand familiarity, as expected. These consumers evaluate luxury brand extensions more rigorously, and use conceptual fit and manufacturer's expertise to produce extension as reference points. The authors further discovered that consumers with a higher level of knowledge displayed more extreme brand evaluations. However, knowledge did

not seem to impact on purchase intention, which is plausible when considering consumers' purchase motivations for luxury brands.

\section{IMPACT OF LUXURY BRAND EXTENSIONS ON PARENT BRAND EQUITY}

Dubois \& Paternault (1995) found that luxury brands lose their prestigious character when over-diffused. This result can be explained by non-personal needs when consumers wish to buy products, which are of high quality, not available to the general public, and/or conform to group members. 
Luxury brand extensions are undertaken to strengthen the core brand image of the parent brand. In order to achieve this objective, the relationship between consumers and the luxury brand must be reinforced. Roux (1995) measured the impact of luxury brand extensions on the parent brand image through brand confidence, brand prestige and desirability. The dependant variables were predicted through conceptual fit, perceived quality of original brand, and transferability. The results showed that brand confidence is only predicted by conceptual fit. Thus, only luxury brand extensions that relate to the original luxury brand's expertise and build brand confidence will have a positive impact on the parent brand. If extensions are inconsistent, brand confidence will decrease and will lead to brand image dilution. Brand prestige is predicted by conceptual fit and brand quality. Transferability significantly contributes to brand prestige, but to a lower extend. Only legitimate luxury brand extensions contribute to brand prestige, assuming the brand has a reputation for quality and possesses the expertise to transfer its credentials. Luxury brand extensions face the challenge to extend target markets, but also maintain the feel of being limited. The objective is to increase consumers' desire for the brand. Conceptual fit and brand perceived quality are the main predictors for desirability. If brand desirability is decreased or not maintained, the brand image for luxury brands will be harmed. People intending to buy luxury brands for ostentatious motives, will remove their demand for these brands. Overall, the results showed that brand confidence, brand prestige and brand desirability are significantly linked with the nature of luxury brand extensions.

Roux \& Boush (1996) further examined the impact of brand extensions on a luxury brand's prestige, desirability and confidence moderated by consumers' knowledge level. The hypothesis, that more knowledgeable people would give the parent brand elements more extreme evaluations, was not supported. This outcome confirms that consumers buy luxury brands because of their image, group influence and emotional benefit. Further, no relationship was found between brand prestige, desirability and confidence, when used as purchase intention variables.

Following the literature review a brand equity framework for extending luxury brands is being developed focusing on the brand equity elements image $\&$ association, and their inter-relationships.

\section{CONCEPTUAL MODEL}

This proposed conceptual model is an extract of the complete model, which is currently being developed and tested as part of a $\mathrm{PhD}$, in which the impact of brand extensions on the parent brand equity of luxury brands is investigated.

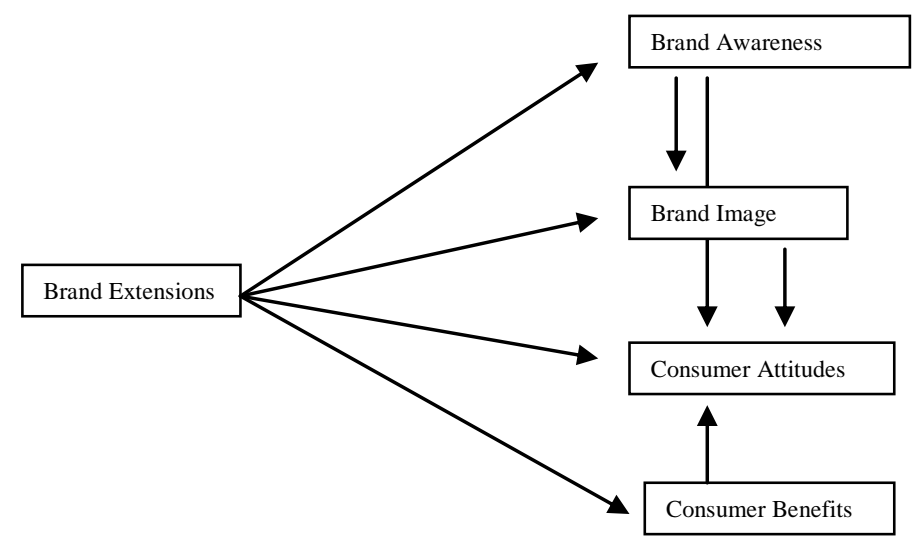




\section{RESEARCH PROPOSITIONS}

Research on non-luxury brands has shown that a major contribution of extensions is the enhancement of brand awareness regardless of the success of the extensions (Aaker 1990; Morrin 1999) and their facilitation of awareness and trial (Tauber 1981; Tauber 1988; Aaker and Keller 1990; Park et al. 1991; Keller 1993; Reddy, Holak and Bhat 1994; Aaker and Joachimsthaler 2000). Morrin (1999) showed that exposure to brand extensions facilitates the speed with which subjects can categorise parent brands correctly. This outcome is moderated for dominating brands (non-dominant brands benefit more), with respect to extension fit (the greater the extension fit, the greater correct categorisation), extension number (the greater the number of extensions, the greater the parent brand retrieval) and product category crowdedness (the more crowded, the slower the recognition level).

It is anticipated that the same outcome is true for luxury brands. However, it is proposed that brand extensions will damage the brand image of luxury brands, as these brands may be seen as widely available and accessible to the majority of people. Consumers usually purchase luxury brands for their symbolic attributes and their distinct values being conspicuous, unique, social, emotional, and quality (Vigneron and Johnson 1999). Especially, luxury brands' strong, unique and favourable associations of being conspicuous and unique will be damaged for the 'Affluent' segment that acquires luxury brands because of these values.

Proposition 1: Brand Extensions For Luxury Brands Will Increase Brand Awareness Of Luxury Brands. However, The Brand Image May Be Damaged Through Increasing Brand Awareness.

Other research has shown that an increasing number of product extensions can lead to a decrease in the leveraging potential of a brand (Tauber 1985; Kesler 1987; Ogiba 1988; Aaker 1990; The Economist 1990). This development is explained by the categorisation theory, with an increasing number of products associated with a brand, the meaning (image) of a brand may be diminished in consumers' mind and it will be more difficult for consumers clearly categorise the products and their extensions (Sujan 1985; Smith and Park 1992).

The image of luxury brands is mainly based on favourable strong association of predominantly symbolic product characteristics. Luxury brands have to be able to create a well-known brand identity and be perceived as exclusive (Phau and Prendergast 2000). The implication is that luxury brands have to maintain the perception of limited supply, which leads to difficulties of increasing sales through greater exposure (Roux and Floch 1996). Brand extensions will damage the perception of limited supply if offered in greater variety whether through line or category extensions. Dubois \& Laurent (1994) found that many luxury goods companies seemed to have lost their exceptional position due to over-diffusion of their products. Sharp (1993) found that premium brands may lose their exceptional place value. Luxury goods brands such as Gucci and Lacoste seriously damaged their brands by introducing line extensions that made the brands widely available and reduced the prestige that comes with restricted availability (Lane and Jacobson 1997).

Further research has suggested that advertising may damage the luxury brand image, which could imply that common brand knowledge is not desirable for luxury brands (Dubois and Paternault 1995; Dubois et al. 2001). Hence, luxury brand extensions increasing brand knowledge may damage a luxury brand's image. Roux \& Boush (1996) found that brand knowledge positively effects quality perceptions of potential brand extensions. However, they did not find support that greater brand knowledge had an effect on conclusions about the effect of brand extensions on the parent brand.

Proposition 2: Brand Extensions Of Luxury Brands Will Damage A Luxury Brand's Image If The Image Of Limited Supply Is Not Maintained, And Luxury Brands Lose Their Exceptional Market Position.

The outcome that luxury brands lose their prestigious character when over-extended (Dubois and Paternault 1995) can be explained by a decrease in the benefits of luxury brand attributes. If consumers buy products for nonpersonal needs such for differentiation purposes, and/or to conform to group members then luxury products become too much commonplace, luxury brands lose their symbolic characteristics, and their exceptional place in the market 
(Dubois et al. 2001). This is especially true for 'Elitists' consuming luxury brands for their conspicuous, uniqueness and social characteristics.

Proposition 3: Brand Extensions Decrease Benefits Of Attributes Inherent To Luxury Brands, If They Are Made Commonplace.

Brand extensions usually increase production, and availability, which may lead towards possible mass productions, and an increase in marketing communications such as advertising. Dubois and Paternault (1995) assumed that advertising may damage the luxury brand image, which could imply that common brand knowledge is not desirable for luxury brands. Hence, luxury brand extensions increasing brand knowledge may lessen attitude towards luxury brands (Dubois and Paternault 1995).

The 'Elitism' segment will oppose luxury brand extensions as they feel that luxury should be reserved for "refined people", who are educated and appreciate the value of luxury goods. They see luxury as a way to differentiate themselves from those who can not afford the premium price. Hence, luxury items are not to be massproduced and made commonplace like in supermarkets (Dubois et al. 2001). These consumers will not buy luxury brands if made commonplace. Their affective attitude will be negative towards extended luxury brands.

Luxury brands are purchased for their uniqueness, scarcity, quality, hedonic and self-expression attributes (Park et al. 1991; Vigneron and Johnson 2004). Brand extensions will decrease the benefits of these attributes, which will lead to an overall decrease in attitudes toward the luxury brand.

Proposition 4: Brand Extensions Will Decrease Overall Brand Attitude Towards Luxury Brands Due To Decreased Brand Image And Decreased Benefits Of Attributes Intrinsic To Luxury Brands.

These propositions amongst others will be tested as part of a wider $\mathrm{PhD}$ research study examining the impact of brand extensions on luxury brands' equity.

\section{CONCLUSION AND FURTHER RESEARCH}

Little research has been done in the luxury market. However, the research findings so far have clearly shown a change in both sides of the market for luxury goods and brands. Research into consumers' attitudes has shown that consumers' purchase motivations are ambivalent as well as complex, and may vary with purchase occasions. This phenomenon has been addressed in research on consumers' perceptions of the degree of luxury, which varies with values consumer seek in purchasing a luxury brand. Both of these research approaches were suggested to be used to segment the luxury market, manage luxury brands, and design suitable marketing strategies. Further research may address the two research approaches used to segment the luxury market, and conduct a comparison study that would allow further insights to develop successful marketing strategies for luxury brands.

Much research can be done in the area of brand equity management for luxury brands, as research in this area has only scratched the surface so far. Especially, in the area of extending luxury brands, it would be useful to identify further factors that facilitate successful brand extensions.

\section{REFERENCES}

1. Aaker, D.A. and Keller, K.L. 1990, Consumer Evaluations of Brand Extensions, Journal of Marketing, vol. 54, no. January, pp. 27-41.

2. Aaker, D.A. 1990, Brand Extensions: The Good, the Bad, and the Ugly, Sloan Management Review, vol. 31, no. 4, pp. 47-56.

3. $\quad$ Aaker, D.A. 1991, Managing Brand Equity, The Free Press, New York.

4. Aaker, D.A. 1996, Measuring Brand Equity across Products and Markets, California Management Review, vol. 38 , no. 3, pp. 102-20. 
5. Aaker, D.A. and Joachimsthaler, E. 2000, The Brand Relationship Spectrum: The Key to the Brand Architecture Challenge, California Management Review, vol. 42, no. 4, pp. 8-24.

6. $\quad$ Aldrich, N.W.J. 1988, Old Money: The Mythology of America's Upper Class, Alfred A. Knopf, New York.

7. Andrus, D.M., Silver, E. and Johnston, D.E. 1986, Status Brand Management and Gift Purchase: A Discriminant Analysis, Journal of Consumer Marketing, vol. 3 (March), pp. 5-13.

8. Arghavan, N. and Zaichkowsky, J.L. 2000, Do Counterfeits Devalue the Ownership of Luxury Brands? Journal of Product \& Brand Management, vol. 9, no. 7, pp. 485-97.

9. Baudrillard, P. 1968, Le Système Des Objets: La Consommation Des Signes, Gallimard, Paris.

10. Baudrillard, P. 1970, La Société De Consommation: Ses Mythes Et Ses Structures, Gallimard, Paris.

11. BBDO Worldwide 1988, Focus: A World of Brand Parity, BBDO, privately published, as cited in Biel 1992.

12. Biel, A. 1992, How Brand Image Drives Brand Equity, Journal of Advertising Research, vol. 32, no. 6, pp. RC6-RC12.

13. Blackston, M. 1995, Copy-Testing and Brand Equity: What's the Connection? Journal of Advertising Research, vol. 35, no. 1, RC2-RC7.

14. Bourdieu, P. 1979, La Distinction: Critique Sociale De Jugement, Les éditions de Minuit, Paris.

15. Bourne, F.S. 1957, Group Influence in Marketing and Public Relations, in Some Applications of Behavioral Research, eds R. Likert and S.P. Haves, Unesco, Paris, France.

16. Dubois, B. 1992, Comment Surmonter Les Paradoxes Du Marketing Du Luxe, Revue Française de Gestion, Janvier-Février, pp. 30-37.

17. Dubois, B. and Duquesne, P. 1993, The Market for Luxury Goods: Income Vs. Culture, European Journal of Marketing, vol. 23, no. 1, pp. 35-44.

18. Dubois, B. and Laurent, G. 1993, Is There a Euro-Consumer for Luxury Goods? in European Advances in Consumer Research, eds F.V. Raaij and G. Bamossy, Association For Consumer Research, Provo, UT, pp. 58-69.

19. Dubois, B. and Laurent, G. 1994, Attitudes toward the Concept of Luxury: An Exploratory Analysis, AsiaPacific Advances in Consumer Research, vol. 1, no. 2, pp. 273-78.

20. Dubois, B. and Laurent, G. 1995, Luxury Possessions and Practices: An Empirical Scale, European Advances in Consumer Research, vol. 2, pp. 69-77.

21. Dubois, B. and Laurent, G. 1996, The Functions of Luxury: A Situational Approach to Excursionism, Advances in Consumer Research, vol. 23, pp. 470-77.

22. Dubois, B., Laurent, G. and Czellar, S. 2001, Consumer Rapport to Luxury: Analyzing Complex and Ambivalent Attitudes, Consumer Research Working Article No. 736, HEC, Jouy-en-Josas, France.

23. Dubois, B. and Paternault, C. 1995, Understanding the World of International Luxury Brands: The 'Dream Formula', Journal of Advertising Research, vol. 35, no. 4, pp. 69-76.

24. Dyson, P., Andy Farr, Nigel S. Hollis 1996, Understanding, Measuring, and Using Brand Equity, Journal of Advertising Research, vol. 36, no. 6, pp. 9-21.

25. Freeman, L. and Sloan, P. 1989, P\&G Tops in Cosmetics: Purchase of Nexell Stings Lintas, Advertising Age, vol. 25 , no. 1 .

26. Heath, R. 1997, Brand Commitment as a Predictor of Advertising Effect, ADMAP (UK), April, pp. $53-57$.

27. Hirschman, E. 1988, Upper Class Wasps as Consumers: A Humanistic Inquiry, in Research in Marketing, ed. E. Hirschman, JAI Press Inc., pp. 115-47.

28. Hirschman, E.C. 1990, Consumption Styles of the Rich and Famous: The Semiology of Saul Steinberg and Malcolm Forbes, Advances in Consumer Research, vol. 17, pp. 850-55.

29. Hoyer, W.D. and Brown, S.P. 1990, Effects of Brand Awareness on Choice for a Common, Repeat-Purchase Product, Journal of Consumer Research, vol. 17, no. 2, pp. 141-48.

30. Kahn, B. 1998, Dynamic Relationships with Customers: High Variety Seeking Strategies, Journal of Academy of Marketing Science, vol. 26, no. 1, pp. 45-53.

31. Kamakura, W.A. and Russell, G.J. 1993, "Measuring Brand Value with Scanner Data", International Journal of Research in Marketing, vol. 10, pp. 9-22.

32. Kapferer, J.-N. 1997, Managing Luxury Brands, Journal of Brand Management, vol. 4, no. 4, pp. 251-60.

33. Kapferer, J.-N. 1998, Why Are We Seduced by Luxury Brands? Journal of Brand Management, vol. 6, no. 1, pp. 44-49. 
34. Keller, K.L. 1993, Conceptualizing, Measuring and Managing Customer Based Brand Equity, Journal of Marketing, vol. 57, no. 1, pp. 1-22.

35. Keller, K.L. 2003, Brand Synthesis: The Multidimensionality of Brand Knowledge, Journal of Consumer Research, vol. 29, no. 4, pp. 595-601.

36. Kesler, L. 1987, Extensions Leave a Brand in New Area, Advertising Age, June 1, p. 1.

37. LaBarbera, P.A. 1988, The Nouveaux Riches: Conspicuous Consumption and the Issue of Self Fulfilment, in Research in Marketing, ed. E. Hirschman, JAI Press Inc, pp. 179-210.

38. Lane, V. and Jacobson, R. 1997, The Reciprocal Impact of Leveraging: Feedback Effects from Brand Extensio Evaluation to Brand Evaluation, Marketing Letters (Neth.), vol. 8, no. 3, pp. 261-71.

39. Leibenstein, H. 1950, Bandwagon, Snob, and Veblen Effects in the Theory of Consumers' Demand, Journal of Economics \& Business, vol. 64 (May), pp. 183-207.

40. Leuthesser, L. 1988, Defining, Measuring and Managing Brand Equity: A Conference Summary, Marketing Science Institute. Cambridge, MA.

41. Levy, M. 1997, Brand Stretching Persuasion Gains Consumer Permission, Brand Strategy, 24 October, M.A.I.D, pp. 3-5.

42. LVMH 2005, Annual Report 2004, (Online serial). Available: 〈http://www.lvmh.com/comfi/pdf_gbr/ra_abrege_2004_gbr.pdf >.

43. Mason, R. 1981, Conspicuous Consumption, St Martin's Press, New York, N.Y.

44. Matorin, J. 2002, Effective Marketing Strategy Helps Ensure Operators Get Their 'Fair Share of Stomach', Nation's Restaurant News, vol. 36, no. 13, pp. 20-22.

45. Milberg, S., Park, W.C. and McCarthy, M.S. 1997, Managing Negative Feedback Effects Associated with Brand Extensions, Journal of Consumers Psychology, vol. 6, no. 2, pp. 119-40.

46. Morrin, M. 1999, The Impact of Brand Extensions on Parent Brand Memory Structures and Retrieval Processes, Journal of Marketing Research, vol. 36, no. 4, pp. 517-25.

47. Nueno, J.L. and Quelch, J.A. 1998, The Mass Marketing of Luxury, Business Horizons, November/December, pp. 61-68.

48. Ogiba, E. 1988, The Dangers of Leveraging, Adweek, January 4, p. 42.

49. Otnes, C., Lowrey, T. and Shrum, L.J. 1997, Toward an Understanding of Consumer Ambivalence, Journal of Consumer Research, vol. 24 (June), pp. 80-94, as cited in Dubois et al. 2001.

50. Park, W.C., Jaworski, B.J. and MacInnis, D.J. 1986, Strategic Brand Concept-Image Management, Journal of Marketing, vol. 50, no. 4, pp. 135-45.

51. Park, W.C., Milberg, S. and Lawson, R. 1991, Evaluation of Brand Extensions: The Role of Product Feature Similarity and Brand Concept Consistency, Journal of Consumer Research, vol. 18, no. 2, pp. 185-93.

52. Phau, I. and Prendergast, G. 2000, Conceptualizing the Country of Origin of Brand, Journal of Marketing Communications, vol. 6, no. 3, pp. 159-70.

53. Reddy, S., Holak, S.L. and Bhat, S. 1994, To Extend or Not to Extend: Success Determinants of Line Extensions Journal of Marketing Research, vol. 31, no. 2, pp. 243-62.

54. Roedder-John, D., Loken, B. and Joiner, C. 1998, The Negative Impact of Extensions: Can Flagship Products Be Diluted? Journal of Marketing, vol. 62, no. 1, pp. 19-33.

55. Roux, E. 1995, Consumer Evaluation of Luxury Brand Extensions, EMAC Conference Proceedings, May, Essec, Paris.

56. Roux, E. and Boush, D.M. 1996, The Role of Familiarity and Expertise in Luxury Brand Extension Evaluation, EMAC Conference Proceedings, May, Budapest, Hungary.

57. Roux, E. and Floch, J.-M. 1996, Gérer L'ingérable: La Contradiction Interne De Toute Maison De Luxe, Décisions Marketing, vol. 9 (September-December), pp. 15-23.

58. Sharp, B.M. 1993, Managing Brand Extension, Journal of Consumer Marketing, vol. 10, no. 3, pp. 11-17.

59. Smith, D.C. and Park, W.C. 1992, The Effects of Brand Extensions on Market Share and Advertising Efficiency, Journal of Marketing Research, vol. 29, no. 3, pp. 296-313.

60. Stanley, T.J. 1989, Selling to the Affluent, Irwin, Homewood, Ill.

61. Sujan, M. 1985, Consumer Knowledge: Effects on Evaluation Strategies Mediating Consumer Judgments, Journal of Consumer Research, vol. 12 (June), pp. 31-46.

62. Swait, J., Erdem, T., Louviere, J. and Dubelaar, C. 1993, The Equlization Price: A Measure of ConsumerPerceived Brand Equity, International Journal of Research in Marketing, vol. 10, no. 1, pp. 23-45. 
63. Tauber, E.M. 1981, Brand Franchise Extension: New Product Benefits from Existing Brand Names, Business Horizons, vol. 24, no. 2, pp. 36-41.

64. Tauber, E.M. 1985, Editorial: Researching Brand Extensions, Journal of Advertising Research, vol. 16 (June/July), p. 6.

65. Tauber, E.M. 1988, Brand Leverage: Strategy for Growth in a Cost-Control World, Journal of Advertising Research, vol. 28, no. 4, pp. 26-30.

66. The Economist 1990, Stretching Brand Names, February, pp. 21-23.

67. UBC Sunsite n.d., Latin Dictonary (Online). Available: 〈www.sunsite.ubc.ca/LatinDictionary>.

68. University of Notre Dame n.d., Latin Dictionary and Grammar Aid (Online). Available: <www.nd.edu/ archives/latgramm.htm>.

69. Vigneron, F. and Johnson, L.W. 1999, A Review and a Conceptual Framework of Prestige-Seeking Consumer Behavior (Online), Academy of Marketing Science Review. Available: $\langle$ http://www.Vancouver.wsu.edu/amsrev/search.htm>.

70. Vigneron, F. and Johnson, L.W. 2004, Measuring Perceptions of Brand Luxury, The Journal of Brand Management, vol. 11, no. 6, pp. 484-506.

71. Weber, D. and Dubois, B. 1995, The Edge of Dream: Managing the Brand Equity in the European Luxury Market, in Values, Lifestyles and Psychographics, eds L. Kahle and M. Chiagouris, Lawrence Elbaum Associates, Hillsdale, N.J.

72. Wong, A.C.Y. and Zaichkowsky, J.L. 1999, Understanding Luxury Brands in Hong Kong, European Advances in Consumer Research, vol. 4, pp. 310-16.

73. Wong, N.Y. and Ahuvia, A.C. 1998, Personal Taste and Family Face: Luxury Consumption in Confucian and Western Societies", Psychology and Marketing, vol. 15 (August), pp. 423-41. 